\title{
On the presence of Heterocarpus ensifer Milne Edwards, 1881 (Decapoda, Pandalidae) in the Spanish Mediterranean
}

\author{
M. García-Rodríguez *, J.L. Pérez-Gil ** and A. Esteban **
}

Heterocarpus ensifer Milne Edwards, 1881, is a benthic deepwater species with a mid-latitude circumglobal distribution extending throughout the eastern and western Atlantic, Indo-west Pacific and Indian Ocean (Holthius, 1980). Its geographic distribution covers from the Indo-Pacific (occurring in the south-west Indian Ocean and possibly Hawaii and Kiribati; Crosnier 1988); the western Atlantic Ocean, from North Carolina to Brazil; and eastern Atlantic Ocean from the South-Western Iberian peninsula (Maurin, 1961, 1962; Ribeiro \& Cascalho, 1987; Sardá et al., 1982) to the Congo ( $5^{\circ} 42^{\prime}$ S), including the archipelagos of Madeira, Canaries and Cape Verde (Crosnier \& Forest, 1973; Holthius, 1980; Lagardere, 1981, Chace, 1985). In the Western Mediterranean, only one example has been recorded previously in Balearic waters (Massutí \& Oliver, 1975; García Socias \& Massuti, 1987), although we do not know of its deposit in any collection.

The appearance of new records of Heterocarpus ensifer in the Spanish Mediterranean, since this is only the second documented record of the species in the Mediterranean, provide data on the size, sex, localisation and depth of appearance of the species, thereby contributing to the understanding of its presence in the Mediterranean.

The material examined consisted of five specimens of Heterocarpus ensifer that came from catches obtained using sets of traps in the course of experimental fishing cruises, carried out in the months of November 1998, March and June 1999, covering the whole of the Spanish Mediterranean coast, including the Balearic Islands and the Alborán Island (García-Rodriguez et al., 2000). The specimens of Heterocarpus ensifer found were preserved frozen until they could be processed in the laboratory. They were measured by their cephalothoracic length (CL), to the nearest 0.1 millimetre, the individual weight $(\mathrm{W})$ was recorded accurately to the nearest 0.1 gram, and the sex was recorded. The sex was determined by the presence or not of masculine appendages in the second pair of pleopods, by dissection under a stereoscopic microscope. A voucher specimen of those caught has been deposited in the Biological Reference Collections of the ICM-CSIC in Barcelona (Code: ICMD 100/2000).

The studied specimens shown a very wide distribution, appearing at the south of the island of Menorca $\left(39^{\circ} 49.235^{\prime} \mathrm{N} ; 03^{\circ} 46.661^{\prime} \mathrm{E} ; 245 \mathrm{~m} ; 25.2\right.$ $\mathrm{mm} \mathrm{Cl}, 7.9 \mathrm{~g} \mathrm{~W})$ in November, the Columbretes Islands $\left(40^{\circ} 10.102^{\prime} \mathrm{N}\right.$; $01^{\circ} 07.316^{\prime} \mathrm{E}$; $306 \mathrm{~m}$; no data) in February, La Mesa (Gata Cape; 36 35.426'N; $02^{\circ} 13.675^{\prime} \mathrm{W} ; 339 \mathrm{~m} ; 31.9 \mathrm{~mm} \mathrm{Cl}, 14.5 \mathrm{~g} \mathrm{~W} ; 26.4$ $\mathrm{mm} \mathrm{Cl}, 9.0 \mathrm{~g} \mathrm{~W}$ ) in May, with two specimens on the same catch, and at El Seco de los Olivos (Almería; $36^{\circ} 32.891^{\prime} \mathrm{N}$; $02^{\circ} 48.752^{\prime} \mathrm{W} ; 364 \mathrm{~m} ; 27.9 \mathrm{~mm} \mathrm{Cl}$, $11.7 \mathrm{~g} \mathrm{~W}$ ) in May. The water temperature at the findings was very homogeneous $\left(12.5^{\circ}-13.3^{\circ} \mathrm{C}\right)$, as would be expected at these depths, characterised by the presence of Levantine Intermediate Waters. All the obtained specimens were females and no one were ovigerous.

In its distribution area, excepting the Mediterranean, $H$. ensifer is a common species that occurs most abundantly in the depth range from 300 to 600 m (Clarke, 1972; Strhusaker \& Aasted, 1974; Gooding, 1984; Gooding et al., 1988; Dailey \& Ralston, 1986). King (1981) reported depth ranges in the south western Pacific islands of 285-760 $\mathrm{m}$. In addition, it has been recorded at $146-885 \mathrm{~m}$

\footnotetext{
* Instituto Español de Oceanografía, Servicios Centrales, Avda. Del Brasil 31, 28020-Madrid-Spain.

** Instituto Español de Oceanografía, Centro Oceanográfico de Murcia, C/ Varadero 1, 30740 San Pedro del Pinatar, MurciaSpain.
} 
(Indo-Pacific) and 200-885 in Atlantic (Chace 1985; Crosnier, 1988, respectively), and between 200 and $350 \mathrm{~m}$ in Palau (Saunders \& Hastie, 1992). In the Canary Islands it is found at depths of 113756 m (González et al., 1992; González \& Santana, 1996; López Abellán et al., 1992); Sardá et al. (1982) found the species at $512 \mathrm{~m}$ deep at the Gulf of Cádiz. The species are mainly found on muddy bottoms, although they have been reported on sandy substrata from the Canary insular shelves and slopes (González et al., 1990), as well as on bottom consisting of fine mud and hexantinellid sponges (González \& Santana, 1996).

There is a very wide variation on the optimum depth and size ranges for $H$. ensifer in other areas, with sizes ranging from 6.5 to $42.0 \mathrm{~mm} \mathrm{Cl}$ (González \& Santana, 1996; King, 1981; Saunders \& Hastie, 1992). In our findings, $H$. ensifer appeared in the shallow zone of the optimum range, but was within the reported bathymetric distribution range. The sizes also appeared to be in the size ranges already observed. All of our findings were in the neighbourhood of islands (Menorca and Columbretes) or submarine rocky banks (Seco de los Olivos and La Mesa), usual fishing grounds for trap lowering. In the case of the Mediterranean first record of the species (Massutí \& Oliver, 1975), a trawl gear was used; this fact contrasts with that along the eight year MEDITS_ES fishing trawl cruises covering the Spanish coast, $H$. ensifer was never caught (Carbonell \& Abelló, 1998). On the other hand, $H$. ensifer is usually caught using traps as literature reflects, despite Sardá et al. (1982) caught twelve individual by trawling in the Gulf of Cádiz. The possibility that Massutí \& Oliver (1975) made a misidentification with another Mediterranean species can be considered, since in 23 years no one has cited this species. Furthermore, the presence of Heterocarpus grimaldii Milne Edwards \& Bouvier (1900) in the Gulf of Cádiz (García-Raso, 1996), a deeper species that can be easily confused with $H$. ensifer, adds uncertain to the matter. In any case, our opinion is that $H$. ensifer distribution in the Mediterranean can be wider than observed until now, due to its mid-latitude circumglobal distribution, and that it could be found more easily at depths below $400 \mathrm{~m}$ and, furthermore, in some areas neighbouring underwater seamounts and islands.

\section{References}

Caldentey, M. A., Santana, J. I., GonzÁlez, J. A. \& LOZANO, I. J., 1992. Observaciones biológico-pes- queras sobre los pandálidos (Crustacea, Decapoda, Caridea) de Canarias. Actas V Simposio Ibérico de Estudios del Bentos Marino, 2: 25-43.

Carbonell, A. \& Abelló, P., 1998. Distribution characteristics of pandalid shrimps (Decapoda: Caridea: Pandalidae) along the Western Mediterranean Sea. Journal of Natural History, 32: 1463-1474.

Chace, F. A., 1985. The caridean shrimps (Crustacea: Decapoda) of the Albatross Philippine Expedition, 1907.1910. Smithsonian Contributions to Zoology, 411: 1-143.

Clarke, T. A., 1972. Exploration for deep benthic fish and crustacean resources in Hawaii. Univ. Hawaii, Technical Report - Hawaii Institute of Marine Biology, 29: 1-18.

Crosnier, A., 1988. Sur les Heterocarpus (Crustacea, Decapoda, Pandalidae) du Sud-oest de l'ocean indien. Remarques sur d'autres especes ouest-pacifiques du genre et description de quatre taxa nouveaux. Bulletin du Muséum National d'Histoire Naturelle, 4ème. série, 10(1): 57-103.

Crosnier, A. \& Forest, J., 1973. Les crevettes profondes de l'Atlantique oriental Tropical. ORSTOM, Série Faune Tropicale, no 19. Paris. 409 pp.

Dailey, M. D. \& Ralston, S. 1986., Aspects of the reproductive biology, spatial distribution, growth and mortality of the deepwater caridean shrimp Heterocarpus laevigatus in Hawaii. Fisheries Bulletin, 84: 915-925.

García Raso, J., 1996. Crustacea decapoda (excl. Sergestidae) from Ibero-Marrccan waters. Results of BALGIM-84 expedition. Bulletin of Marine Science, 58(3): 730-752.

García-Rodríguez, M., Esteban, A. \& Pérez-Gil, J.L., 2000. Considerations on the biology of Plesionika edwardsi (Brandt, 1851) (Decapoda, Caridea, Pandalidae) from experimental trap catches in the Spanish Western Mediterranean Sea. Scientia Marina, 64(4): 369-379.

García Socias, L. L. \& Massutí, J. 1987., Inventari bibliografic dels Crustacis Decápodes de les Balears (Crustacea, Decapods). Bolletí de la Societat d'Història Natural de les Balears. 31: 67-92.

González, J. A, Caldentey, M. A. \& Santana, J. I. 1990. Catálogo de las especies de la familia Pandalidae (Crustacea, Decapoda, Caridea) en Canarias. Vieraea, 19: 141-151.

GonzÁlez, J. A. \& SAntana, J. I., 1996. Shrimps of the family Pandalidae (Crustacea, Decapoda,) off the Canary Islands, Eastern Central Atlantic. South African Journal of Marine Sciences, 17: 173-182.

Gooding, R. M., 1984. Trapping surveys for the deepwater Caridean shrimps Heterocarpus laevigatus and $H$. ensifer, in the Northwestern Hawaiian Islands. Marine Fisheries Review, 46(2):18-26. 
Gooding, R. M., Polovina, J. J. \& Dailey, M. D., 1988. Observations of deepwater shrimp, Heterocarpus ensifer, from a submersible off the island of Hawaii. Marine Fisheries Review, 50(1): 32-39.

Holthuis, L. B., 1980. FAO species catalogue: An annotated catalogue of species of interest to fisheries. Vol. 1. Shrimps and prawns of the world. FAO Fisheries Synopsis, 125(1): 1-271.

KING, M. G., 1981. Deeepwater shrimp resources in Vanatu: A preliminary survey off port Vila. Marine Fisheries Review, 43(12): 10-17.

KInG, M. G. \& MoffitT, R. B., 1984. The sexuality of tropical deepwater shrimps (Decapoda: Pandalidae). Journal of Crustacean Biology, 4(4): 567-571.

Lagardere, J. P., 1981. Crevettes In: W. Fischer, G. Bianchi and W.B. Scott (Eds). Fiches FAO d'identification d'espèces pour les besoins de la pêche. Atlantique Centre-Est. Zones de Pêche 34, 47. 6. FAO. Rome: various pages.

López Abellán, L. J., García Santamaría, M. T. \& BAlguerías Guerra, E., 1992. Resultados de la campaña experimental de pesca realizada en aguas del sur de la isla de Tenerife "Canarias 9206". Instituto Español de Oceanografía. Santa Cruz de Tenerife. 117 pp.

Massutí, M. \& Oliver, P,. 1975. Iniciación al estudio de nuevos fondos de arrastre en el talud continental de las islas Baleares. Publicaciones Técnicas de la Dirección General de Pesca Marítima, 10: 153-167.

MAurin, C., 1961. Répartition des crevettes profondes sur les côtes profondes sud du bassin occidental de la Méditerranée et dans la région ibero-marocaine. Rapports et procès verbaux des réunions Commission Internationale pour l'exploration Scietifique de la Mer Méditerranée, 16(2): 529-532.
MAurin, C., 1962. Étude des fonds chalutables de la Méditerranée occidentale (écologie et pêche). Résultats des campagnes des navires océanographiques "President Theodore-Tissier", 1957 à 1960, et "Thalassa", 1960 et 1961. Revue des Travaux de l'Institut des Pêches Maritimes, 26: 163-218.

SARdÁ, F., Valladares, F. J. \& Abelló, P., 1982. Crustáceos Decápodos y Estomatópodos capturados durante la campaña "Golfo de Cádiz 81". Resultados Expediciones Cientificas 10: 89-100

Saunders, W. B. \& Hastie, L. C. 1992. Remote camera and trapping survey of the deep-water shrimps Heterocarpus laevigatus and $H$. ensifer and the Geryonid crab Chaceon granulatus in Palau. Marine Fisheries Review, 54(1):15-25.

Strhusaker, P. \& Aasted, D. C., 1974. Deep-water shrimp trapping in the Hawaiian Islands. Marine Fisheries Review, 36(10): 24-30.
Recibido, el 26-II-2002

Aceptado, el 17-V-2002

Publicado, el 5-IX-2002 